Western University Scholarship@Western

Political Economy Research Group. Papers in

Political Economy

Economics Working Papers Archive

1995

\title{
The Limits of Rent-Seeking: Why Protectionists Become Free Traders
}

Michael Lusztig

Follow this and additional works at: https://ir.lib.uwo.ca/economicsperg_ppe

Part of the Economics Commons

Citation of this paper:

Lusztig, Michael. "The Limits of Rent-Seeking: Why Protectionists Become Free Traders." Political Economy Research Group. Papers in Political Economy, 61. London, ON: Department of Economics, University of Western Ontario (1995). 
POLITICAL

ECONOMY

RESEARCH

GR O UP

\title{
PAPERS IN POLITICAL ECONOMY
}

Paper No. 61

"The Limits of Rent-Seeking: Why Protectionists Become Free Traders"

\author{
Michael Lusztig
}

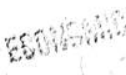

(4) 21 to

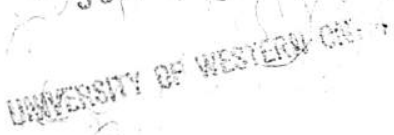

5

J11 21989

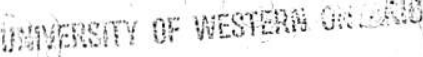

The UNIVERSITY of WESTERN ONTARIO 
The Political Economy Research Group was established in the faculty of/Social Science at the University of Western Ontario in 1988. Its purpose is to foster scholarship, teaching and interdisciplinary research in political economy, with a focus on:

1. the application of economic-models and methods to the study of political processes and institutions,

2. the économic impact of political processes and institutions,

3. the influence of economic factors on the formation of public policy and on institutional change,

4. the politics of economic policy making,

5. the political, social, and economic effects of public policy.

Co-directors:

Ronald Wintrobe (Economics)

Robert Young (Political Science)

Board of Directors:

Peter Howitt (Economics)

B.B. Kymlicka (Political Science)

John N. McDougall (Political Science)

Peter Neary (History)

John Whalley (Economics)

Staff:

Jayne Dewar

For further information:

Political Economy Research Group,

Department of Economics,

Social Science Centre,

London, Ontario, Canada N6A $5 \mathrm{C} 2$

phone: (519) 661-3877

fax: (519) 661-3292 
ISSN:

ISBN:

1181-7151

0-7714-1779-9

$-41855$

The Limits of Rent-Seeking:

Why Protectionists Become Free Traders

Michael Lusztig

Department of Political Science

University of Western Ontario

London, Ontario N6A 5C2

CANADA

lusztig@sscl.uwo.ca 
A critical issue within international political economy concerns the means by which popularly elected governments overcome domestic political obstacles to trade liberalization. Perhaps the most significant obstacle is widespread opposition by rent-seeking producer groups. ${ }^{1}$ It is broadly accepted that free trade constitutes an 'asymmetric' public good, whereby the benefits are widely distributed, but latent, while the costs to those who had enjoyed rents derived from the insulation of the domestic market are concentrated and manifest. ${ }^{2}$ Given this fact, an equally important issue emerges: even if governments successfully legislate free trade, why is it that in many cases, domestic rent-seekers do not continue to lobby the government for a return to protectionism?

Insofar as it explains why domestic rent-seekers alter their trade policy demands, this paper demonstrates one way in which governments successfully might overcome an important source of domestic opposition to the enactment and maintenance of free trade policies. First, it develops a model to suggest that given certain conditions, rent-seeking opponents of trade liberalization actually may turn into critically important allies of governments attempting major policy shifts from protectionism to free trade. It argues that where domestic rent-seekers are persuaded that the government cannot or will not provide sufficient rents, rent-seekers may pursue a second-most preferred strategy that entails attempting to secure access to foreign markets by actively supporting trade liberalization.

The next section applies the model to three cases where formerly protectionist rentseekers became advocates of trade liberalization following clear signals that their governments no longer were able (or willing) to supply rents. In the United States, many industrialists who had opposed liberalization of trade and monetary policy during the 1930s, became important advocates of freer trade by the beginning of World War II, and supported US leadership of the General Agreement on Tariffs and Trade (GATT) in the post-war era. This change in policy preferences, it is argued, was stimulated by the Roosevelt Administration's decision to reduce the availability of state-suplied rents. Similarly, in Canada, despite historic and widespread opposition to continental free trade among most of the manufacturing community, by the early 1980s, following significant industrial tariff cuts mandated by the Tokyo Round of the GATT, the same manufacturing community was in the forefront of the battle for the Canada-US Free Trade Agreement (CUFTA). Finally, Mexican business effectively blocked Mexico's proposed membership in the GATT in 1980. When international pressure and economic crisis ultimately

${ }^{1}$ Rent-seeking entails the attempt to use the power of the state to transfer, rather than create, wealth (John A.C. Conybeare, "Tariff Protection in Developed and Developing Countries: A Case Sectoral and Longitudinal Analysis, "International Organization 37 (1983), pp. 441-467).

2 Sam Peltzman, "Toward a More General Theory of Regulation," Joumal of Law and Economics 15 (1976), pp. 211-240; Gordon Tullock, "Future Direction for Rent Seeking Work," in Charles Rowley, Robert Tollison and Gordon Tullock, eds., The Political Economy of RentSeeking (Boston: Kluwer Academic, 1988); Robert E. Baldwin, "The Political Economy of Trade Policy," Journal of Economic Perspectives 3 (1989), pp. 119-135. 
drove Mexico to decrease direct subsides to business and to reduce import protection drastically, much of the business sector switched its trade policy demands, and supported a North American Free Trade Agreement (NAFTA).

The third and final section of the paper briefly analyzes the broader implications of the findings. It demonstrates how the model advances the literature within international political economy. It also highlights the prescriptive element of the model for governments seeking to eliminate deadweight costs associated with import protection. Finally, it suggests that the model can be applied to a greater range of cases than the three examined in this paper.

\section{The Limits of Rent-Seeking}

Protectionism, it is widely held, tends to be inefficient. Devices such as tariffs, import licenses, quotas, and voluntary export restrictions impose deadweight costs onto society at large. Because it skews incentive structures within the marketplace, import protection diverts resources from sectors enjoying comparative advantage towards those which operate less efficiently. ${ }^{3} \mathrm{An}$ important qualification, however, concerns infant industries. Industries in newly developed countries, potentially competitive in world markets save for catch-up costs associated with lateentry into the game, might efficiently be protected in the early years of their development. Most industrializing countries, therefore, have allowed their nascent manufacturing sectors to develop behind tariff walls.

Nevertheless, such a strategy has the potential to generate pernicious externalities. Domestic protectionism provides incentives for producers to emerge in sectors that suffer comparative and competititve disadvantage. In many cases, such producers can exist only as long as the state provides sufficient import protection. Even for industries in other, potentially more competitive sectors, import protection may discourage innovation and international competitiveness. As long as production for the domestic market is profitable, there may be no incentive to assume the risks of restructuring operations to compete in world markets. ${ }^{4}$ In short,

${ }^{3}$ Gordon Tullock, "Welfare Costs of Tariffs, Monopolies and Theft," Western Economic Journal 5 (1967), pp. 224-232; Anne Krueger, "The Political Economy of the Rent-Seeking Society," American Economic Review 64 (1974), pp. 291-303.

${ }^{4}$ In fact, inertia may prolong protectionist policies even after they become suboptimal. Judith Goldstein points to post-war opposition by American farmers to agricultural trade liberalization under the GATT as an example. "The more autarchic policies promoted by agricultural groups were "functional" in the 1940s. However, worldwide trade liberation was a superior policy choice since it would have met both the short-term and long-term interests of the farming sector" (Judith Goldstein, "Creating the GATT Rules: Politics, Institutions, and American Policy," in John Gerard Ruggie, ed., Multilateralism Matters: The Theory and Praxis of an Intemational Form (New York: Columbia University Press, 1993), p. 226). Indeed, insofar as American farmers were internationally competitive, the failure to liberalize agricultural trade under the GATT meant that foreign markets, potentially receptive to American agricultural exports, were 
protectionist strategies designed to provide temporary shelter for infant industries become institutionalized, and governments seeking to reduce tariff rates significantly face opposition from powerful domestic rent-seekers. ${ }^{5}$

It is for this reason that departure from the tradition of protectionism is so difficult politically. Conversely, because radical shifts towards trade liberalization do occur, it is clear that the policy is not wholly intractable. Moreover, experience shows that countries that open their economies to external competition often are able to maintain free trade, while fighting only limited rear-guard battles with domestic rent-seekers. Indeed, under such circumstances, former protectionists tend to be in the forefront of the fight for further liberalization of trade. The United States in the post-war era is an obvious example. Similarly, although a shorter time-frame is involved, the same phenomenon appears to have taken place in Canada and Mexico. Clearly then, there exists some mechanism whereby many domestic rent-seekers are transformed from enemy to ally in the fight for free trade.

\section{Flexible Versus Inflexible Rent-Seekers}

Rent-seekers do not constitute a single, monolithic entity. Indeed, it is important to distinguish between two broad, ideal-typical categories of rent-seeker. Domestic producers whose capital is immobile, and who have invested in industries or sectors that could not possibly compete internationally, are styled inflexible rent-seekers. For these, state-supplied rents are all that stand between survival and bankruptcy. The second ideal-typical form of rent-seeker prefers domestic protection to international competition, but conceivably could restructure operations to compete internationally. These are styled flexible rent-seekers.

An obvious problem with such a distinction is identification. All rent-seekers portray themselves as inflexible. Producer groups do not make public statements or submit depositions admitting that they pursue protectionism and/or direct subsidies as a means of generating greater profits. ${ }^{6}$ Rather, they tend to argue that a loss of import protection/subsidy will result in

rendered less-accessible.

5 Of course, not all domestic producers in countries with high tariff walls are protectionist. Sectors that export efficiently, and which thus have geared production to compete internationally, will seek reduction of tariffs in order to lower the costs of factor inputs and to encourage tariff reduction abroad. Where firms have developed effective multinational operations (including integrated global production and intrafirm trade flows) there will be even greater resistance to protectionism. Helen Milner, "Trading Places: Industries for Free Trade," in John S. Odell and Thomas D. Willet, eds., International Trade Policies: Gains from Exchange between Economic and Political Science (Ann Arbor: University of Michigan Press, 1993).

${ }^{6}$ State-provided rents extend beyond import protection and direct subsidies. Regulatory legislation, for example, which inhibits entry into certain economic sectors, is but one other form of rent. Indeed, the larger the domestic market-share of a protected industry, the more likely it is to have a stake in the continuation of import protection. See Real Lavergne, The 
business failure, job loss, and economic decline. On the other hand, while both flexible and inflexible rent-seekers utilize the same tactics in seeking rents, other actions provide contrast. Specifically, differences between flexible and inflexible rent-seekers leave historical traces. It is relatively easy, therefore, to distinguish flexible from inflexible rent-seekers ex post facto, when rent-seeking activity is unsuccessful. Inflexible rent-seekers will continue to lobby the government to restore cuts to import protection/subsidy, even if such effort appears fruitless. Faced with the prospect of certain demise, it is rational to continue fighting to the last, no matter how steep the odds. Ultimately, of course, inflexible rent-seekers will be notable by their failure to survive. Under the same circumstances, flexible rent-seekers, having been denied their optimal preference, will not waste resources fighting a battle that almost certainly will not be won. Rather, they will pursue a second-most preferred strategy. This entails restructuring operations to face the new challenges posed by having to face increased competition. This restructuring includes seeking to secure new markets for export to replace market-shares lost at home. Under such circumstances, many flexible rent-seekers will become ardent supporters of free-market trade policies.

It is important to re-emphasize that flexible and inflexible rent-seekers are ideal-typical classifications. Therefore, certain qualifications are necessary. Thus, while most rent-seekers ultimately will conform to the characteristics of one category or the other, some rent-seekers demonstrate characteristics associated with both flexible and inflexible rent-seekers. ${ }^{7}$ Similarly, as certain industries decline, they may shift from being flexible rent-seekers to those demonstrating mixed characteristics, and begin pressing for increased protectionism. ${ }^{8}$

It is also important to note that many industries will not enjoy the prescience to predict ahead of time to which category of rent-seeker they conform. However, this does not constitute a serious problem for the current analysis. All that such uncertainty suggests is that there may be a time-lag between the elimination of state-supplied rents and the predicted behavior of domestic rent-seekers. Over the short-term, rent-seekers unable to guage their international competitiveness may be expected to conform to the predicted behavior of both flexible and inflexible rent-seekers. That is, they will lobby for restoration of state-supplied rents and restructure operations to compete in world markets. Eventually, it will become clear to flexible rent-seekers that they can compete, and they will modify their behavior. Thus, rather than

Political Economy of U.S. Tariffs (Toronto: The Academic Press, 1983); cf Milner, "Trading Places."

7 A good example of this is continued lobbying for protection on the part of certain American industries during the post-war era. Sectors such as footwear and textiles, for example, while not weak enough to be eliminated under free trade, are not strong enough to benefit from trade liberalization. As a result, such sectors have continued to lobby (with occasional success) for the restoration of limited protectionism.

${ }^{8}$ To use the American example again, such industries might include consumer electronics, steel, and automobiles. 
lobbying for restoration of rents, newly aware flexible rent-seekers will switch tactics and lobby for greater access to foreign markets.

\section{Trade Policy Change at the National Level}

The key to the transformation flexible rent-seeker demands from protection to free trade is the demonstration by the government that it cannot or will not provide sufficient rents to make protectionism more profitable than free market policies. In this sense the process may, or may not, be deterministic. Under certain circumstances, the transformation of rent-seeker demands turns on factors beyond the control of government. One such factor is severe economic crisis. Crises generate increased and more widespread demands on governments to distribute public resources. At the same time, however, governments find that during times of economic hardship, there are fewer resources available for distribution. The result, therefore, tends to be a decline in each rent-seeker's share of state-supplied rents.

A somewhat less deterministic factor is pressure from international regimes such as the GATT, World Bank, or International Monetary Fund (IMF) to reduce the supply of rents. Under these circumstances, governments must choose whether or not to comply with the dictates of the regime. However, because it is widely accepted in most countries that membership in such regimes is economically beneficial, governments may make credible claims that they had no option but to reduce the availability of state-supplied rents.

Finally, under some circumstances, the decision to reduce state-supplied rents constitutes an act of free will on the part of governments. On occasion, it may serve the state's interest to reduce rents, even at the expense of alienating rent-seekers. Political entrepreneurs seeking to effect electoral realignments, for example, may reduce rents (such as tariffs) if doing so helps attract support (from free-trading interests) for the new electoral coalition. In other words, political entrepreneurs with a second-order preference for free trade may seek to reduce rents as a byproduct of realizing larger objectives. ${ }^{9}$ In this sense, state-supplied rents are conceptualized as resources to be redistributed selectively in the construction of a minimum winning coalition. ${ }^{10}$ Entrepreneurs seeking to alter the composition of the winning coalition merely choose to shift the distribution of resources away from protectionists.

Alternatively, governments with a first-order preference for freer trade also might seek to reduce rents by gambling that initial opposition to free trade will be offset by long-term support for the policy by flexible rent-seekers. While this is an admittedly risky course of action, it does suggest a prescriptive component to the model advanced here.

In sum, the policy conversion of flexible rent-seekers has important long-term

9 Author, 1993.

${ }^{10}$ William H. Riker, The Theory of Political Coalitions (New Haven: Yale University Press, 1962). 
implications for trade policy. Because inflexible rent-seekers are culled from the producer population with the reduction of state-supplied rents, pro-free trade producers assume a proportionately stronger voice. Future policies of trade liberalization will be supported actively, especially as increased international economic interdependence creates further incentives to keep markets open. ${ }^{11}$ Similarly, in the absence of marked shifts toward competitive disadvantage, or of market-distorting factors such as severe economic depression or unfair trade practices abroad, protectionism is more likely to be resisted by flexible rent-seekers long into the future. The model is presented in Figure 1.

Figure 1 here

Some additional caveats are required before proceeding. First, it is important to note that the model does not suggest that the transformation of flexible rent-seeker preferences automatically leads to future policies of freer trade. Producer groups exercise considerable influence over government, but their voice is not decisive. Other sources of domestic opposition -- labor and cultural organizations are important examples -- may dissuade governments from pursuing greater trade liberalization.

A second caveat is that domestic economies feature sources of dynamism other than that stimulated by the reduction of state-supplied rents. Factors such as technological development, reduced transport costs, major wars, and shifting access to markets abroad, may stimulate flexible rent-seekers to operate more efficiently in order to increase exports, and no longer seek protection at home. ${ }^{12}$ These groups will lobby for free trade independently of state reduction of rents.

On the other hand, while it is important to recognize the importance of these domestic factors, none is able to account for the creation and maintenance of support for free trade policies in the three cases examined here. In Canada, and to a lesser-extent Mexico, long traditions of business support for continental protectionism were reversed extremely quickly. While the case conceivably can be made that factors such as technological change and reduced transport costs affected business attitudes, it is not clear what specific developments could have triggered so rapid a reversal in the policy demands of the business communities. Indeed, the

${ }^{11}$ Helen Milner, Resisting Protectionism: Global Industries and the Politics of International Trade (Princeton, Princeton University Press, 1988); Ibid., "Trading Places."

${ }^{12}$ Thomas Ferguson, "From Normalcy to New Deal: Industrial Structure, Party Competition, and American Public Policy in the Great Depression, "International Organization 38 (1984), pp. 41-94; Peter A. Gourevitch, Politics in Hard Times: Comparative Responses to International Economic Crises (Ithaca: Cornell Universtiy Press, 1986); Scott C. James and David A. Lake, "The Second Face of Hegemony: Britain's Repeal of the Com Laws and the American Walker Tariff of 1846," International Organization 43 (1989), pp. 1-29; Ronald Rogowski, Commerce and Coalitions: How Trade Affects Domestic Political Alignments (Princeton: Princeton University Press, 1989). 
twentieth century has been replete with examples of significant technological change, which, while undoubtedly responsible for changing trade policy demands among some within the Mexican and Canadian business communities, did not trigger rapid, widespread reversals in policy demands. ${ }^{13}$

The American case is more problematic. The intervention of World War II, and concommitant technological advances, undoubtedly had some impact on the trade policy preferences of American business between 1934 and the creation of the GATT. Indeed, the devastation of Europe clearly improved the competitiveness of American producers. On the other hand, the intervention of a major war cannot explain the proclivity of most American industrialists to maintain support for free trade long after competitors in Europe and Japan had recovered and begun to challenge American hegemony in manufacturing. Moreover, evidence (discussed below) suggests that big business was widely supportive of internationalism and trade liberalization prior to the outbreak of war. Finally, the intervention of the war does not explain why American farmers, who were internationally competitive and traditionally free-trading (but who continued to derive significant state-supplied rents in the post-war era), were vocal opponents of extension of the GATT to the agricultural sector. ${ }^{14}$

A final objection that might be raised is that trade policy preferences among business leaders changed in all three countries as the result of market closure abroad. While intuitively sound, this hypothesis stands up poorly to closer inspection. In the United States, for example, market closure in Europe occured in direct response to the Smoot-Hawley Tariff. Yet, as discussed below, as late as 1939 (nine years after world markets closed), a strong majority of US businessmen preferred higher tariffs to lower ones. In Canada, while the case can be made that rising US protectionism in the early 1980s constituted a threat, it is important not to overemphasize this point. ${ }^{15}$ Even in 1982, when congressional action against foreign imports

${ }^{13}$ Moreover, at least in Canada, studies have shown that the advantages of free trade with the United States were probably greater in the 1960s than in later decades (Paul Wonnacott and Ronald J. Wonnacott, Free Trade Between the U.S. and Canada (Cambridge: Harvard University Press, 1967); William G. Watson, "Canada-U.S. Free Trade: Why Now?" Canadian Public Policy 13 (1987), pp. 337-349). In spite of this, Canadian business remained protectionist until the 1980s. (Canada, Parliament, Senate Standing Committee on Foreign Affairs, CanadaUnited States Relations Volume 2 (Ottawa: Minister of Supply and Services, 1978); Duncan Cameron, "Introduction," in Duncan Cameron, ed., The Free Trade Papers (Toronto: James Lorimer, 1986); G. Bruce Doern and Brian W. Tomlin, Faith and Fear: The Free Trade Story (Toronto: Stoddart, 1991)).

${ }^{14}$ Goldstein, "Creating the GATT Rules."

15 Indeed, as Milner notes: "While it is commonly believed that protectionism grew substantially in the 1970s and early 1980s, US trade policy actually had mixed currents." (Milner, "Trading Places," p. 147). 
reached its height, only a fraction of cases targeted Canada, with even fewer of these being successful. ${ }^{16}$ Finally, in Mexico, NAFTA was initiated in 1990, well after the deepest wave of US protectionism had passed. Moreover, prior to the opening of the Mexican economy in the middle of the 1980s, the bulk of Mexican exports were in minerals and crude oil, products not threatened by US protectionism. ${ }^{17}$

Analysis now turns to an application of the model to the American, Canadian and Mexican cases.

\section{The Cases: The United States, Canada and Mexico}

The cases selected for study reflect a most-different-case design. They were chosen to demonstrate applicability of the model across variations in time, structure of government, and industrial development. Similarly, the cases reflect cases of both democratic and pre-democratic government. Finally, with the recent trilateral ratification of NAFTA, the cases represent parts of a common theme of increasing interest to trade policy scholars.

\section{The United States}

Trade policy conversion among US flexible rent-seekers began with the Reciprocal Trade Agreements Act (RTAA) and the Tripartite Monetary Agreement (TMA) in the mid-1930s, both of which gradually reduced the availability of state-supplied rents in the industrial sector. Shortly after the passage of the RTAA and the negotiation of the TMA, flexible rent-seekers within big business altered their trade policy demands. By the end of World War II, moreover, small- and medium-sized flexible rent-seekers also had become advocates of international trade liberalization under the GATT. The decision to reduce the availability of state-supplied rents was mandated by the political objectives of President Roosevelt. Upon the failure of his protectionist "First" New Deal coalition, Roosevelt sought to construct a second coalition that included, among other groups, internationally oriented business and financial interests. ${ }^{18}$

As early as the Tariff Act of 1816, American rent-seekers were active, and usually successful, in lobbying Congress for high barriers to imports. Indeed, most of the nineteenth

${ }^{16}$ Watson, "Free Trade, Why Now?" p. 340. As Watson notes: "despite increased protection, Canada enjoyed great success in penetrating US markets in the early 1980 s, even in those industries where special protection was introduced." (bid.)

${ }^{17}$ See Miguel D. Ramirez, "Stabilization and Trade Reform in Mexico: 1983-1989," Joumal of Developing Areas 27 (January 1993), pp. 183-184.

${ }^{18}$ Gourevtich, Politics in Hard Times; a fuller discussion of this argument is found in Author (1993). 
century was characterized by moderate to high rates of import protection. ${ }^{19}$ By the twentieth century, protectionism was well-entrenched, both institutionally (through congressional tariffmaking), and through the orientation of the business community. Indeed, the so-called 'System of '96' entailed almost universal support from business for the protectionist and tight money platform of the Republican party. ${ }^{20}$ Prior to American entry into World War I a slight liberalizing trend, supported by an emerging export-oriented sector, led to the 1913 Underwood Tariff and, three years later, to the establishment of the Tariff Commission. The trend was short-lived. The Tariff Commission, whose original mandate was to provide a counterweight to protectionist special interests in the tariff-making process, instead became an instrument of protectionists. ${ }^{21}$

The ineffectiveness of the Tariff Commission was not the only factor leading to increased protectionism during the 1920 s. Republican control of the presidency and Congress stimulated a return to higher tariffs and economic nationalism, as did depressed agricultural prices at home, and depreciated currencies abroad. Similarly, despite the war's role in increasing the competitiveness of certain American industrial and financial interests globally (which created some pressure to lower tariffs), new infant industries (or war babies) joined the battle for protectionism. ${ }^{22}$ The full force of this rising protectionism was manifested in the Smoot-Hawley

${ }^{19}$ See J.J. Pincus, Pressure Groups and Politics in Antebellum Tariffs (New York: Columbia University Press, 1977); Robert A. Pastor, Congress and the Politics of U.S. Foreign Economic Policy, 1929-1976 (Berkeley: California University Press, 1980).

${ }^{20}$ Ferguson, "From Normalcy to New Deal." The System of '96 was an electoral realignment that saw the Republican Party dominate from 1896 to 1932.

${ }^{21}$ The Commission was intended as an alternative to (self-interested) producer groups as a source of information for Congress. In addition, after 1922 the Commission was responsible for tendering advice to the President on the implementation of the 'flexible tariff' - a new presidential power that allowed him to raise or lower tariffs on specific items to appropriate levels - taken to be those that equalized production costs between foreign and domestic producers (F.W. Taussig, The Tariff History of the United States 8h ed. (New York: Augustus M. Kelley, 1967)). The Tariff Commission's mandate was problematic on three counts. First and most obviously, the cost-of-production equalization principle was inherently protectionist, serving, in effect, to institutionalize compensation for comparative and competitive disadvantage. Second, because the determination of production costs at home and abroad for even a single item was so time-intensive, the Commission could provide only very specialized information on a narrow range of products. Finally, the Commission proved little use as a counterweight to special interests, because while the elected Congress had great incentive to heed the advice of voting constituents, it had relatively little to listen to that of Tariff Commission bureaucrats.

22 William B. Kelly, Jr., "Antecedents of Present Commercial Policy," in William B. Kelly, Jr., Studies in United States Commercial Policy (Chapel Hill: University of North Carolina Press, 1963). 
Tariff of 1930.

Smoot-Hawley represents the zenith of American protectionism in the twentieth century. ${ }^{23}$ Originally introduced as a means of compensating farmers for existing levels of industrial protection, the eighteen month bargaining process deteriorated into a virtual bazaar for state-supplied rents. Congressional tariff-making based on information provided by self-interested economic lobbyists inspired what Cordell Hull described as "a continuous round of political and legislative debauches with graft aforethought. ${ }^{\text {"24 }}$

Smoot-Hawley accelerated the decline of a world economy already in the grips of severe depression. ${ }^{25}$ America's trading partners, deeply in debt due to war loans and tight lending practices in the United States after 1928, had relied on export-led growth as a means of remaining economically solvent. The closing of the US market pre-empted this strategy, and compelled other countries to retaliate in kind. As a result, world exports fell by fifty percent between 1928 and 1932. US exports declined by sixty-six percent over the same period. Domestically, US Gross National Product (GNP) fell from \$104 billion in 1929 to \$58 billion three years later. Unemployment increased thirty-fold.

President Roosevelt's response to the crisis was to stay the nationalist and isolationist course charted by his predecessor Herbert Hoover. In fact, by taking the United States off the gold standard in 1933 in order to depreciate the dollar (effectively ruining any chance of international monetary cooperation) Roosevelt actually increased the supply of rents available

\footnotetext{
${ }^{23}$ Under Smoot-Hawley, tariffs reached an ad valorem average of 53\%. Milner, "Trading Places."

${ }^{24}$ Quoted in William R. Allen, "The International Trade Philosophy of Cordell Hull, 19071933," American Economic Review 43 (1953), p. 115. The classic analysis of rent-seeking during the Smoot-Hawley debates is E.E. Schattschneider, Politics. Pressures and the Tariff (New York: Prentice-Hall, 1935). See also Joseph Jones, Tariff Retaliation: Repercussions of the Hawley-Smoot Bill (Philadelphia: University of Pennsylvania Press, 1934); John Day Larkin, Trade Agreements (New York: Columbia University Press, 1940); Taussig, The Tariff History of the United States; Stephen Robert Brenner, "Economic Interests and the Trade Agreements Program, 1937-1940: A Study of Institutions and Political Influence," Ph.D. dissertation, Stanford University, 1978; Lavergne, The Political Economy of U.S. Tariffs; and Stephan Haggard, "The Institutional Foundations of Hegemony: Explaining the Reciprocal Trade Agreements Act of 1934," International Organization 42 (1988), pp. 91-119.

${ }^{25}$ Charles P. Kindleberger, The World in Depression 1929-1939 (Berkeley: University of California Press, 1973).
} 
to domestic industrialists. ${ }^{26}$ This, of course, was done at the expense of the financial sector. The abandonment of the gold standard (and the later decision to remonetize silver) entrenched a deepening rift within the business community. Indeed, led by the financial sector, an important segment of the business community already had began to lobby for internationalist policies of monetary cooperation and trade liberalization. ${ }^{27}$ Roosevelt's subsequent decision to reduce statesupplied rents, under the auspicies of the RTAA and the TMA, thus was made easier by the knowledge that he would not be opposed by a united business community. Moreover, the failure of the First New Deal -- an attempt to create a quasi-corporatist arrangement between state, business and agriculture -- ended with significant opposition to Roosevelt among the conservative (and protectionist) business community. This further reduced the costs of alienating conservative business with the reduction of state-supplied rents.

The RTAA and TMA ${ }^{28}$ constituted a significant, if incremental, opening of the United States market, and hence a substantial reduction of state-supplied rents. ${ }^{29}$ The RTAA,

${ }^{26}$ For a discussion of Roosevelt's decision to place domestic priorities ahead of international cooperation at the World Economic Conference of April 1933 see Arthur M. Schlesinger, Jr., The Coming of the New Deal (Boston: Houghton Mifflin, 1958); Kindleberger, The World in Depression; James R. Moore, "Sources of New Deal Economic Policy: The International Dimension," Journal of American History 61 (1974), pp. 728-744; Robert Dallek, Franklin D. Roosevelt and American Foreien Policy, 1932-1945 (New York: Oxford University Press, 1979); Jeff Frieden, "Sectoral Conflict and Foreign Economic Policy, 1914-1940," International Organization 42 (1988), pp. 59-90); and Daniel Bennett Smith, Toward Internationalism (New York: Garland, 1990).

${ }^{27}$ Ferguson, "From Normalcy to New Deal;" Frieden, "Sectoral Conflict and Foreign Economic Policy."

${ }^{28}$ The Tripartite Agreement was a pact among Britain, France and the United States which restored the currencies of all three countries to gold convertability, and committed each to mutual consultation prior to currency devaluation. The Agreement attracted participation from Belgium, the Netherlands and Switzerland, ultimately laying the foundations for the post-war dollar standard established at Bretton Woods (Harold Van B. Cleveland, "The International Monetary System in the Interwar Period," in Benjamin M. Rowland, ed., Balance of Power or Hegemony (New York: New York University Press, 1976); Dallek, Franklin D. Roosevelt and American Foreign Policy; and Frieden, "Sectoral Conflict and Foreign Economic Policy;"

${ }^{29}$ Brenner provides the most comprehensive history and description of the RTAA (Brenner, "Economic Interests and the Trade Agreements Program." See also William S. Culbertson, Reciprocity (New York: Whittlesay House, 1937); Henry J. Tasca, "The Reciprocal Trade Policy of the United States," Ph.D. dissertation, University of Pennsylvania, 1938; Francis Sayre, The Way Forward: The American Trade Agreements Program (New York: Macmillan, 1939); Larkin, Trade Agreements; Cordell Hull, The Memoirs of Cordell Hull Volume 1 (New York: Macmillan, 1948); Pastor, Congress and the Politics of U.S. Foreign Economic Policy; 
especially, was important for a number of reasons. First, it eliminated the cost-of-production equalization principle, and with it, legislative protection for comparative and competitive disadvantage. Second, it re-affirmed the unconditional most-favored-nation (MFN) principle in world trade, a principle that was to become a bedrock of the GATT. ${ }^{30}$ Third, it led to a steady decline in US tariff rates after 1934. Finally, it made rent-seeking more difficult by shifting the authority to set tariff levels from Congress to the more-insulated executive branch. ${ }^{31}$

The RTAA was initially unpopular with domestic rent-seekers, and at its introduction (as well as its prewar triennial renewals) was opposed strongly. Among the most powerful oppponents were elements of the big business community represented by the American Liberty League and the National Association of Manufacturers (NAM). ${ }^{32}$ In addition, numerous national industrial sectoral associations appeared (or submitted depositions) before Congress in opposition to the RTAA and/or its renewals. ${ }^{33}$ In fact, as late as the autumn of 1939 , an Elmo

Haggard, "The Institutional Foundations of Hegemony;" and Carolyn Rhodes, Reciprocity. U.S. Trade Policy, and the GATT Regime (Ithaca: Cornell University Press, 1993).

${ }^{30}$ The unconditional MFN principle holds that treatment offered to any most-favored-nation must be offered unconditionally to all other such countries. In this way there should be a ratchet effect toward international liberalization of trade. The unconditional MFN had been introduced in 1922, but given the protectionist climate of the 1920s merely resulted in the extension of the same bad treatment to all countries. After the implementation of the RTAA, and the commitment to liberalizing trade, the Roosevelt administration remained divided for almost a year over whether reciprocal agreements would operate under the principle of conditionality or unconditionality.

${ }^{31}$ It is important to note that while the RTAA was pertinent to all sectors of the economy, agricultural interests still derived significant state-supplied rents through direct subsidies and price supports under the Agricultural Adjustment Act.

${ }^{32}$ It should be noted that the big business community was divided by the mid-1930s, with a significant portion already supporting economic internationalism (Ferguson 1984; Gourevitch 1986; Frieden 1988). The NAM had traditionally been an organization controlled by small- and medium-sized firms. However, from the start of the New Deal onward, the organization was firmly controlled by big business (Philip H. Burch Jr., "The NAM as an Interest Group," Politics and Society 4 (1973), 97-130).

${ }^{33}$ United States, Congress, House of Representatives, Committee on Ways and Means. Hearings, on H.R. 8430. Reciprocal Trade Agreements (Washington: United States Government Printing Office, 1934); United States, Congress, Senate, Committee on Finance, Hearings, on H.R. 8687. Reciprocal Trade Agreements (Washington: United States Government Printing Office, 1934); United States, Congress, House of Representatives, Committee on Ways and Means, Hearings, on H.J. Res. 96. Extension of Reciprocal Trade Agreements Act (Washington: United States Government Printing Office, 1937); United States; Congress, Senate, Committee 
Roper poll found that 26.6 percent of American businessmen favored higher tariffs compared to only 10.7 percent advocating lower ones. ${ }^{34}$

However, the cumulative effect of the gradual reduction of state-supplied rents in the second half of the 1930s ultimately led to behavior predicted by the model. With respect to flexible rent-seekers, it seems clear that by the 1940 renewal of the RTAA, a shift in policy preference toward trade liberalization had occured. In 1940, for the first time, a majority of those appearing before, and submitting depositions to, the House Ways and Means Committee supported renewal. Indeed, non-agricultural and non-labor interests supported renewal by a rate of more than three to one. ${ }^{35}$ By the early to mid-1950s, the transformation of American business interests was even more clear. A 1954 survey undertaken by Raymond Bauer, Ithiel de la Sola Pool and Lewis Anthony Dexter asking practically the same question as the 1939 Roper poll, found that seven times as many businessmen supported lowering tariffs as those advocating an increase in the tariff rate. ${ }^{36}$

As might be expected by the gradual reduction of state-supplied rents, flexible rentseekers in the United States changed their trade policy preferences incrementally. The fastest switchers were large manufacturers. ${ }^{37}$ As early as 1939 , only seven percent of large manufacturers favored raising tariffs. ${ }^{38}$ Conversely, in 1939 small manufacturers (forty-two percent) and small retailers (forty-seven percent) were still quite strongly in favor of tariff

on Finance, Hearings, on H.J. Res. 96. Extension of Reciprocal Trade Agreements Act (Washington: United States Government Printing Office, 1937); United States, Congress, House of Representatives, Committee on Ways and Means, Hearings, on H.J. Res. 407. Extension of Reciprocal Trade Agreements Act (Washington: United States Government Printing Office, 1940); United States, Congress, Senate, Committee on Finance, Hearings, on H.J. Res. 407. Extension of Reciprocal Trade Agreements Act (Washington: United States Government Printing Office, 1940); Brenner, "Economic Interests and the Trade Agreements Program."

${ }^{34}$ Fortune, October 1939, p. 96.

${ }^{35}$ United States, House Ways and Means Committee, Hearings on H.J. Res. 407 (1940).

${ }^{36}$ Raymond A. Bauer, Ithiel de la Sola Pool, and Lewis Anthony Dexter, American Business and Public Policy 2d ed. (Chicago: Aldine-Atherton Inc., 1972), pp. 113-116.

${ }^{37}$ This suggests that the time lag for the effects of tariff reductions to impact upon smalland medium-sized firms was longer than it was for large firms. See Bauer, Pool and Dexter, American Business and Public Policy, pp. 113-116.

${ }^{38}$ Large manufacturers are those that produced $\$ 50$ million $\cdot$ worth of goods per annum. 
increases. ${ }^{39}$ Yet by 1954 , only five percent of small firms still prefered higher tariffs.

The behavior of inflexible rent-seekers is more difficult to document. Bankruptcy rates in the United States increased substantially during the late $1930 \mathrm{~s} .{ }^{40}$ Allowing for some lag time between the implementation of the RTAA and TMA, and their detrimental effects on inflexible rent-seekers, it is plausible to conclude that the elimination of state-supplied rents doomed numerous inflexible rent-seekers. On the other hand, other factors, such as the recession of 1937, certainly contributed to the increase in bankruptcies. What is clear is that by the 1950s, and throughout the post-war era, the majority of American industrial enterprises have supported general liberalization of trade. The implication is that most rent-seekers either were flexible, or were rationalized out of the market. ${ }^{41}$

In sum, as the availability of state-supplied rents decreased between the mid-1930s and mid-1940s, an increasing number of flexible rent-seekers began to pursue their alternative policy choice: expanded trade liberalization. The internationalist outlook of much of the American business community has persisted throughout the post-war era. Indeed, despite fears of rising protectionism since the early 1970s, business has been a critical force resisting protectionism in the United States. ${ }^{42}$ In addition to its consistent support of the GATT, the business community provided powerful support for the two recent continental free trade initiatives: CUFTA and NAFTA.

\section{Canada}

The conversion of flexible rent-seekers in Canada occured later and far more quickly than was the case in the United States. International pressure from the GATT forced Canada to reduce its industrial tariff rates drastically beginning in 1979. By 1981-82, flexible rent-seekers in the important national sectoral business confederations abandoned the protectionist policies they had advocated for a century, and lobbied the government intensively for CUFTA and, later, NAFTA.

${ }^{39}$ Small manufacturers are those that produced $\$ 50$ thousand to $\$ 1$ million worth of goods per year; small retailers are those that sold $\$ 10$ thousand to $\$ 30$ thousand worth of goods per year.

${ }^{40}$ United States, Bureau of the Census, Historical Statistics of the United States. Colonial Times to 1970 Bicentennial ed. (Washington: United States Government Printing Office, 1975), p. 912.

${ }^{41}$ As noted, firms in certain sectors have not conformed to the characteristics of either category of rent-seeker. These firms have not embraced free trade, nor have they disappeared. Moreover, many firms periodically have sought localized protection, often in the form of nontariff barriers (NTB), and often ostensibly to combat "unfair" trading practices abroad.

${ }^{42}$ Milner, Resisting Protectionism; Ibid., "Trading Places." 
Like the United States, Canada's economic history is largely one of protectionism. In 1879 Canada erected its National Policy -- entailing a system of tariffs that effectively sealed-off the domestic market. The National Policy was designed to foster the emergence of a viable indigenous manufacturing sector. However, rather than serving as a springboard for international competitiveness, the National Policy tariff structure became institutionalized, supported by politically powerful rent-seeking industrialists.

Prior to the 1988 CUFTA, the National Policy tariff structure was challenged seriously only once. ${ }^{43}$ In 1911, the incumbent Liberal government negotiated a free trade agreement with the US. However, in the election of that year, the big business lobby, led by the Canadian Manufacturers Association (CMA), mobilized significant popular opposition, and succeeded in denying the Liberals a mandate to enact free trade. ${ }^{44}$

After 1911, continental free trade was a political non-issue for almost seventy-five years, as industrial rent-seekers made their protectionist preferences clear to government. ${ }^{45}$ The Canadian manufacturing sector continued to produce largely for the protected domestic market, which provided small economies of scale, and encouraged the emergence of small firms. While this led to a proliferation of industrial enterprises in the central Canadian provinces of Quebec and Ontario, it created structural dependence. Small firms were unable to afford state-of-the-art technological innovation, and instead found it more profitable to import technology from the United States. This strategy of import-substituting-industrialization (ISI) characterized industrial development in Canada for much of the 20th century. ${ }^{46}$

${ }^{43}$ Some qualifications are necessary. Canada signed bilateral accords with the United States in 1935 and 1938 under the terms of the RTAA. Similarly, it entered into a free trade deal with the US on automobiles and automotive parts in 1965. Finally, Canada has participated actively in the GATT throughout the post-war era. None of these agreements, however, obviated the importance of the National Policy tariff structure (Canada, Royal Commission on the Economic Union and Development Prospetcs for Canada, Report (Ottawa: Minister of Supply and Services, 1985); Sidney Weintraub, "Canada Acts on Free Trade," Joumal of Interamerican Studies and World Affairs 28 (1986), pp. 101-118; Gilbert R. Winham, Trading With Canada (New York: Priority Press, 1988).

44 According to the Royal Commission on the Economic Union and Development Prospects for Canada, "...the Liberal loss demonstrated the power and resolve of central Canada's manufacturing interests, which had grown and thrived behind the protective walls of the National Policy" (Canada, Royal Commission on the Economic Union and Development Prospects for Canada, Report, p. 223).

45 Ibid.

46 ISI, like other forms of protectionism, contains certain inherent long-term limitations. In the short term, however, the benefits are substantial. The first, or easy, phase of ISI is characterized by the emergence of industries dedicated to production of consumer goods for the 
The era of international trade liberalization following the Second World War did little to alter Canadian industrial practices. Tariff reductions under the GATT in secondary manufacturing were minimal in the immediate post-war decades, and multilateral commitments exerted very little pressure on the National Policy tariff structure. ${ }^{47}$ Thus, it was not until the Kennedy Round of the GATT (1963-1967) that Canada's protectionist trade policy once again became an issue. ${ }^{48}$

The Kennedy Round was characterized by sizeable, across-the-board tariff reductions in manufacturing by most industrialized states. ${ }^{49}$ Canada lobbied against such comprehensive reductions, insisting that because most of its exports were in low-tariff resources while the majority of its imports were in price-sensitive manufactured goods, the Kennedy Round tariff cuts would be unduly punitive and would provide few benefits. Instead, Canada sought to negotiate item-by-item reductions on selected products, thereby emerging from the Kennedy Round with much higher industrial tariff levels than the United States or members of the

domestic market. These industries flourish in the absence of effective foreign competition. Rapid industrial growth stimulates the economy, and creates incentives for expansion in the industrial sector. However, the potential for growth beyond the domestic market is limited. Because ISI involves the importation of technology from abroad, domestic production tends to follow existing trends rather than seeking to develop new products. As a result, these products rarely are able to penetrate world markets. More seriously, ISI renders domestic industry dependent on continued import protection. See Albert O. Hirschman, "The Political Economy of ImportSubstituting Industrialization in Latin America," in Albert O. Hirschman, ed., A Bias for Hope (New Haven: Yale University Press, 1971).

${ }^{47}$ Frank Stone, Canada the GATT and the International Trade System (Montreal: The Institute for Research on Public Policy, 1984); Michael M. Hart, Canadian Economic Development and the International Trading System (Toronto: University of Toronto Press, 1985); G.E. Salembier, Andrew R. Moroz and Frank Stone, The Canadian Import File: Trade, Protection and Adjustment (Montreal: The Institute for Research on Public Policy, 1987).

${ }^{48}$ Bilaterally, trade policy with the United States also remained largely protectionist in the post-war era. Economic nationalism was manifested in policies that sought to lessen Canada's trade dependence on the United States. In 1958, for example, Prime Minister John Diefenbaker announced Canada's intention to divert twenty percent of its cross-border trade to Great Britain; in the early 1970s the government of Pierre Trudeau attempted a similar strategy.

49 Most countries reduced industrial tariffs by an average of approximately thirty-five percent, representing seventy percent of the value of dutiable goods. About two-thirds of these products featured tariff reductions of fifty percent or more (Colleen Hamilton and John Whalley, "The GATT and Canadian Interests," in John Whalley, ed., Canada and the Multilateral Trading System (Toronto: University of Toronto Press, 1985)). 
European Community. ${ }^{50}$

However, the reprieve earned by Canadian manufacturers was to be short-lived. During the Tokyo Round of GATT negotiations, completed in 1979, Canadian industrial tariffs were reduced significantly, seriously undermining for the first time the historic protection afforded by the National Policy tariffs. The Tokyo Round cuts, which bound Canada to the tariff reductions in secondary manufacturing that had been avoided in the Kennedy Round, were opposed by much of the business community. ${ }^{51}$ These reductions were large, averaging thirtyfour to forty percent across industrial sectors, and lowering the average import duty on manufactured goods from approximately fifteen percent to roughly nine to ten percent. ${ }^{52}$ In addition, Canada's valuation formula - the means by which it assesses the market value of goods before the imposition of tariffs - was altered after the Tokyo Round to correspond more exactly with the formula utilized by other GATT members. ${ }^{53}$

The reaction of most businesses to the Tokyo Round tariff reductions was consistent with that postulated for flexible rent-seekers. Not only did most firms expend little effort in lobbying the government for renewed protectionism, but they actively embraced free trade as a means of expanding and restructuring their operations. As early as 1981, two years after the Tokyo Round cuts, the largest business confederations in Canada -- including the big business lobby Business Council on National Issues (BCNI), the Canadian Chamber of Commerce, and the notoriously protectionist Canadian Manufacturers Association and Canadian Federation of Independent

${ }^{50}$ Canada, Royal Commission on the Economic Union and Development Prospetcs for Canada, Report; John Whalley, Colleen Hamilton and Roderick Hill, Canadian Trade Policies and the World Economy (Toronto: University of Toronto Press, 1985).

${ }^{51}$ Canada, Senate Standing Committee on Foreign Affairs, Canada-United States Relations (1978).

52 Canada, Department of External Affairs, A Review of Canadian Trade Policy (Ottawa: Minister of Supply and Services, 1983); Stone, Canada. The GATT and the International Trade System, 1984; Hamilton and Whalley, "The GATT and Canadian Interests."

${ }^{53}$ Whalley, Hamilton and Hill, Canadian Trade Policies and the World Economy. Previously Canada had imposed its tariffs on the "fair market value" of a good, which to protect against dumping, often was determined by the Canadian government (Hart, Canadian Economic Development and the International Trading System; Salembier, Moroz and Stone, The Canadian Import File). Since the Tokyo Round, in compliance with new GATT rules, duties have been imposed on actual market prices, further reducing the level of import protection (Canada, External Affairs, A Review of Canadian Trade Policy). 
Business (CFIB) -- began to lobby strongly for a free trade agreement with the United States..$^{54}$ The volte-face on the part of the business community was remarkable for its rapidity. Long among the country's staunchest opponents of continental free trade, the major business confederations in the country reversed a century-old policy demand for protectionism in a matter of two to three years. ${ }^{55}$

The business community, remarkably cohesive on the trade issue, was instrumental in the passage of CUFTA. After the announced resignation of the nationalist Prime Minister Pierre Trudeau in February 1984, the business community redoubled its efforts to commit the government to continental free trade. Throughout 1985 and 1986 big business continued to lobby senior ministers and bureaucrats in Ottawa, action facilitated by the fact that the BCNI and CMA

${ }^{54}$ Canada, Parliament, House of Commons, Standing Committee on External Affairs and International Trade, Minutes of Proceedings (Ottawa: Minister of Supply and Services, November 3, 1987); David Langille, "The Business Council on National Issues and the Canadian State," Studies in Political Economy 24 (1987), pp. 41-85; Duncan Cameron, "Resisting Free Trade," Canadian Journal of Political and Social Theory 12 (1988), pp. 202-211; Doem and Tomlin, Faith and Fear; Interview with Jock A. Finlayson, Director of Research, Business Council on National Issues, January 6, 1993).

${ }^{55}$ Perhaps the starkest illustration of this reversal can be seen in the parliamentary testimony of the CMA. Compare the comments of Laurent Thibault, ultimately President of the CMA, on free trade with the United States, in 1976: "We have some problems with the theory of free trade. With regard to comparative advantage, basically, everybody does his own thing, and the total is bigger, but the problem we have with the theory is that it does not guarantee, particularly in a small country, vis-a-vis the United States, that we will get our share of the action;" and 1987: "...I think it is important for the committee to know that we find the manufacturing community very supportive of this [CUFTA] right across the country. We find it quite ironic that despite statements by a number of people in politics who are against the agreement, they certainly do not reflect the views of the manufacturing community in our forums across the country" (Canada, Parliament, Senate, Standing Committee on Foreign Affairs, Minutes of Proceedings (Ottawa: Minister of Supply and Services, November 18, 1976; Canada, Parliament, House of Commons, Standing Committee on External Affairs and International Trade, Minutes of Proceedings (Ottawa: Minister of Supply and Services, November 18, 1987). Similarly, see the testimony of John Bulloch, President of the CFIB, in 1977 and 1987 (Canada, Parliament, Senate, Standing Committee on Foreign Affairs, Minutes of Proceedings (Ottawa: Minister of Supply and Services, May 26, 1977; Canada, Parliament, House of Commons, Standing Committee on External Affairs and International Trade, Minutes of Proceedings (Ottawa: Minister of Supply and Services, November 3, 1987). The BCNI also abandoned the protectionist position it had adopted since its creation in 1976 (Doern and Tomlin, Faith and Fear). 
enjoyed a good degree of access to government decision-makers during this period. ${ }^{56}$

The business community continued to play an important role in the free trade process even after the government committed itself to free trade in September 1985. Throughout 1986 and 1987 the BCNI especially lobbied the provincial governments to support the free trade initiative. ${ }^{57}$ The business sector was instrumental in the creation of the free trade lobby group Canadian Alliance for Trade and Job Opportunities, which spent \$1.3 million in support of the Conservatives during the 1988 election campaign, thereby helping to ensure victory for the free trade party. ${ }^{58}$ More recently, the Canadian business community has stood strongly in favor of increased trade liberalization under the Uruguay Round of the GATT and NAFTA. ${ }^{59}$

As in the American case, the behavior of inflexible rent-seekers is more difficult to guage. While numerous businesses failed in the aftermath of the Tokyo Round tariff cuts, it is difficult to isolate the effects of diminished import protection from those of the severe recession of the early 1980s. On the other hand, the cohesiveness of the Canadian business on trade liberalizing initiatives of the mid- to late-1980s, and early-1990s, suggests that most rent-seekers either switched trade policy preferences or failed to survive. ${ }^{60}$

Mexico

The most recent example of producer-group transformation from rent-seeking to trade advocacy occured in Mexico during the 1980s. The severe economic crisis of the early 1980s dramatically curtailed the state's ability to provide economic rents in the form of direct subsidies to business. As importantly, international pressure from institutions such as the IMF, as well as the economic imperatives of the crisis, forced reduction in the level and scope of import

${ }^{56}$ Cameron, "Introduction;" Michael Atkinson and William Coleman, The State, Business, and Industrial Change in Canada (Toronto: University of Toronto Press, 1989); Francois Rocher, "Canadian Business, Free Trade and the Rhetoric of Economic Continentalization," Studies in Political Economy 35 (1991), pp. 135-154; Jack R. Richardson, "Free Trade: Why Did it Happen?" Canadian Review of Sociology and Anthropology 29 (1992), pp. 307-328). Doern and Tomlin note, for example, that representatives of the BCNI and CMA had almost daily contact with Canada's chief trade negotiator, Simon Reisman, during the negotiating period (Doren and Tomlin, Faith and Fear).

${ }^{57}$ Finlayson, interview.

${ }^{58}$ Graham, Fraser, Playing for Keeps rev. ed. ((Toronto: McClelland and Stewart, 1990).

${ }^{59}$ Finlayson, interview.

${ }^{60}$ Again analagous to the American experience, some firms that have survived (especially in the agricultural, railway steel, distillery, and fisheries sectors) continued to press for renewed general protection, and for localized NTBs. Such enterprises, however, represent a small minority within the business community. 
protection. Much of the Mexican business community changed its trade policy demands over the course of the 1980s. By the early 1990s, therefore, while many of the least-efficient businesses had failed, the more competitive ones had become advocates of further trade liberalization under NAFTA.

Even more than its North American neighbors, Mexico shielded its nascent manufacturing sector from foreign competition. From the 1940s until Mexico's 1986 entry in the GATT, Mexico maintained one of the highest levels of import protection in Latin America. ${ }^{61}$ Protectionism benefited all sectors of the economy in the initial decades of the post-war era. Economic prosperity brought fiscal and monetary stability that attracted foreign investors who, along with investment from the public sector, contributed to the construction of a solid industrial infrastructure. ${ }^{62}$ In fact, between 1950 and 1970, the Mexican economy grew by an average rate of 6.7 percent annually. ${ }^{63}$ The engine that powered the economic prosperity of the post war years was import substituting industrialization.

Nevertheless, by the early 1970s, most of the growth-potential of ISI in Mexico had been realized. Faced with the prospect of declining economic growth, President Luis Echeverria sought to stimulate the economy through deficit financing. Increasingly public sector needs were met with funds borrowed from abroad. The discovery of new oil reserves in 1977 increased the availability of credit to Mexico and accelerated borrowing on the part of the government. But by the early 1980s, the slump in oil prices, combined with global recession, dashed Mexico's hopes of economic recovery. So severe were the effects of these blows that by August 1982 Mexico announced that it could no longer afford to service its massive foreign debt.

In spite of such economic turbulence, domestic manufacturers in the 1970s and early 1980 s resisted strongly policies that would have liberalized Mexico's structure of import controls. ${ }^{64}$ For example, Mexico announced in 1980 that it would not seek membership in the GATT as it had proposed to do the previous year. Although some support for multilateral trade

${ }^{61}$ Dale Story, "Trade Policy in the Third World: A Case Study of the Mexican GATT Decision," International Organization 36 (1982), pp. 767-794.

${ }^{62}$ Gerardo Bueno, "The Structure of Protectionism in Mexico," in Bela Balassa et al., eds., The Structure of Protection in Developing Countries (Baltimore: Johns Hopkins University Press, 1971).

${ }^{63}$ Sidney Weintraub, Mexican Trade Policy and the North American Community (Washington: Center for Strategic and International Studies, 1988).

${ }^{64}$ Weintraub, Mexican Trade Policy and the North American Community; Luis Rubio, "Economic Reform and Political Change in Mexico," in Riordan Roett, ed., Political and Economic Liberalization in Mexico: At a Critical Juncture? (Boulder, Lynne Reinner, 1993); Riordan Roett, "At the Crossroads: Liberalization in Mexico," in Roett, Political and Economic Liberalization in Mexico). 
liberalization existed within Mexico's business community, passionate opposition from within the private sector scuttled the GATT initiative. ${ }^{65}$

Until the early 1980s, business enjoyed a mutually profitable relationship with the state. Not only did the government supply generous subsidies to industry, but labor was extremely tightly regulated, allowing for the maximization of profits. Indeed, the distribution of profits in Mexico witnessed twice as great a share going to business as to labor -- the reverse of the distribution in the United States. Finally, tight government regulation of society-at-large provided a stable environment in which to conduct business. Under these optimal conditions, economic nationalism "became the banner under which Mexican entrepreneurs extracted unearned rents from the general public. ${ }^{n 66}$

As the economic climate grew increasingly worse during the 1980s, Mexico began to suffer less autonomy in terms of fiscal and foreign economic policy. The government could no longer afford to provide economic rents at the same rate as in the past. Subsidies such as cheap energy and support for research and development, for example, all but stopped after 1982. At the same time, the government began to allow market forces to rationalize the least-efficient Mexican industries. ${ }^{67}$ In terms of trade policy, the government was under pressure from institutions such as the IMF to liberalize trade. As a result, tariffs came down slightly in 1983, and by 1985, Mexico had begun slowly to dismantle its comprehensive system of import licensing. ${ }^{68}$

${ }^{65}$ Story, "Trade Policy in the Third World;" Roderic Ai Camp, Entrepreneurs and Politics in Twentieth Century Mexico (New York: Oxford University Press, 1989); Diane E. Davis, "Mexico's New Politics: Changing Perspectives on Free Trade," World Policy Journal 9 (1992), pp. 655-671.

${ }^{66}$ Sidney Weintraub and M. Delal Baer, "The Interplay Between Economic and Political Opening: The Sequence in Mexico," Washington Ouarterly 15 (1992), pp. 189-190; see also Blanca Heredia, "Profits, Politics and Size: The Political Transformation of Mexican Business," in Douglas A. Chalmers, Maria do Carmo Campello de Souza and Atilio A. Boron, eds., The Right and Democracy in Latin America (New York: Praeger, 1992); Soledad Loaeza, "The Role of the Right in Political Change in Mexico, 1982-1988, " in Chalmers, de Souza and Boron, eds., The Right and Democracy in Latin America; and Rubio, "Economic Reform and Political Change in Mexico."

${ }^{67}$ Calvin P. Blair, "Mexico's National Program for Industrial Promotion and Foreign Trade, 1984-1988," Mexican Forum 5 (1985), pp. 1-6; Peter S. Cleaves and Charles J. Stephens, "Business and Economic Policy in Mexico," Latin American Research Review 26 (1991), pp. 187-202.

${ }^{68}$ David Brooks, "The Future: Who Will Manage it?" NACLA's Latin America and Empire Report 21 (1987), pp. 21-29; Ramirez, "Stabilization and Trade Reform in Mexico." 
For the business sector, the impact of the state's inability to provide sufficient rents was felt early. In September 1982, the debt crisis forced the nationalization of the country's banks. Moreover, the destabilizing effects of the crisis meant that the government could no longer provide a social climate conducive to productive enterprise. In 1985, compelled by the deterioration of the domestic economy, Mexico petitioned the GATT for inclusion. Even before this decision, part of the business community, faced with a dramatic decrease in state-supplied rents, had begun to mobilize for the introduction of free market policies and an end to economic statism. ${ }^{69}$

The GATT decision of 1985-86 was divisive and controversial within the business community. Small- and medium-sized businesses especially, were opposed, but big business organizations, such as the Mexican Confederation of Industrial Chambers (CONCAMIN) and the Mexican Chamber of Employers (COPARMEX), also disliked the idea of opening the economy. ${ }^{70}$ The effects of joining the GATT were almost immediate. Tariff rates and the aggregate value of goods requiring import licenses fell precipitously after $1986 .{ }^{71}$ At the same time, however, the manufacturing sector enjoyed a surge of productivity. Manufactured goods rose to fifty-five percent of exports in 1989, up from fourteen percent in 1982. Indeed, since the opening of the economy under the GATT, the average rate of growth in manufacturing exports has been 22.4 percent. $^{72}$

By the late 1980s, although still in a state of transition, flexible rent-seeker preferences largely had changed. The second half of the decade witnessed the transformation of partisan

${ }^{69}$ See the interview with Ernesto Martens, CEO of Vitro, Sociedad Anomina, in Nancy A. Nichols, "From Complacency to Competitiveness," Harvard Business Review 9-10 (1993), pp. 162-172. Indeed, the New York Times (July 23, 1992) cites aides to President Carlos Salinas de Gortari, as well as independent economists, that the sharpest adjustment costs to business occurred immediately after 1982, as a result of the economic crisis and the "withering internal market."

70 Matilde Luna, Ricardo Tirado and Francisco Valdes, "Businessmen and Politics in Mexico, 1982-1986," in Sylvia Maxfield and Ricardo Anzaldua Montoya, eds., Government and Private Sector in Contemporary Mexico (San Diego: Center for U.S.-Mexican Studies, 1987); Camp, Entrepreneurs and Politics in Twentieth Century Mexico; Ramirez, "Stabilization and Trade Reform in Mexico;" Judith Teichman, "Dismantling the Mexican State and the Role of the Private Sector," in Ricardo Grinspun and Maxwell A. Cameron, eds., The Political Economy of North American Free Trade (Montreal: McGill-Queen's University Press, 1993).

${ }^{71}$ Tariff rates fell from an average ad valorem rate of over fifty percent prior to joining the GATT to roughly nine percent by 1991 . Similarly, import licenses were virtually eliminated by 1991 (M. Delal Baer, "North American Free Trade," Foreign Affairs 70 (1991)). Mexico."

72 Baer, "North American Free Trade;" Ramirez, "Stabilization and Trade Reform in 
allegiance of much of the business community away from the ruling Partido Revolucionario Institucional (PRD), toward the center-right Partido Accion Nacional (PAN) ${ }^{73}$ In fact, so dramatic was the change in trade policy preference of the business sector, that part of the political rationale for pursuit of even greater economic liberalization under NAFTA was to entice business back to the PRI. ${ }^{74}$

Inflexible rent seekers in Mexico appear to have suffered the same fate as their counterparts in the United States and Canada. The toy and consumer electronics sectors, for example, have been decimated as the result of trade liberalization..$^{75}$ Other industries also have suffered. The period 1989-1991 witnessed unprecedented levels of bankruptcy in Mexico. Indeed, because many businesses failed to fill out the proper documentation, the actual number of business failures was certainly even higher than official records suggest. ${ }^{76}$

In sum, by 1991, the combined effects of the conversion of flexible rent-seeker.policy advocacy and the elimination of inflexible rent-seekers was clear. A Los Angeles TimesProspectiva Estrategica A.C. (Peac) national survey found that 66.8 percent of business owners supported NAFTA compared to just 11.7 percent opposed. ${ }^{n}$

\section{Conclusion}

This paper has sought to explain how popularly elected governments in the United States, Canada and Mexico have been able to gain and maintain support of rent-seeking producer groups in the liberalization of trade. In addition, it has developed a model that may be extended to other cases. This model has a number of important implications.

First, it reinforces the notion that trade policy need not be structurally determined by the preferences of societal forces. ${ }^{78}$ In a prescriptive sense, this implies that democratically elected governments may have a good deal more flexibility in the making of trade policy than the

${ }^{73}$ Loaeza, "The Role of the Right in Political Change in Mexico;" M. Delal Baer, "Mexico's Second Revolution: Pathways to Liberalization," in Roett, ed., Political and Economic Liberalization in Mexico.

${ }^{74}$ Baer, "Mexico's Second Revolution."

${ }^{75}$ Rubio, "Economic Reform and Political Change in Mexico."

${ }^{76}$ Ramirez, "Stabilization and Trade Reform in Mexico," p. 183.

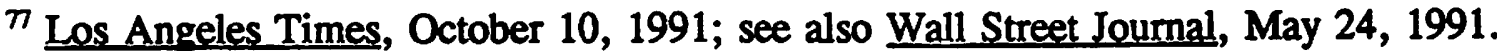

${ }^{78}$ G. John Ikenberry, David A. Lake and Michael Mastanduno, "Introduction: Approaches to Explaining American Foreign Economic Policy, "International Organization 42 (1988), pp. 1-14. 
prevailing literature currently suggests. ${ }^{79}$ In this sense it also makes a contribution to an emerging literature about the conditions under which states are able to enact policies with broadbased (but shallow) social appeal, yet which offend concentrated (but deeply-committed) interests. $^{80}$ In other words, it challenges the dominant (demand-driven) theory that small, concentrated and homogenous groups consistently will subvert the national interest in the framing of public policy. ${ }^{81}$

A second important contribution of the model is that it complements and extends existing theories within international political economy. Indeed, the emphasis on the demise of inflexible rent-seekers reinforces Milner's position that the business sector is an important force resisting protectionism in the United States. ${ }^{82}$ The model builds upon Milner's argument in a number of ways. First, it provides antecedent explanations about how free trade policies come to be passed. Second, the model explains why business shifts its preferences from protectionism to free trade. ${ }^{83}$ Third, the present argument strengthens Milner's theory by suggesting that because

${ }^{79}$ On the political risks and logistical difficulties in overcoming domestic rent-seeking see Tullock, "Welfare Costs of Tariffs;" Ibid., " Future Directions for Rent-Seeking Work;" Krueger, "The Political Economy of the Rent-Seeking Society;" Peltzman, "Toward a More General Theory of Regulation;" Frey, International Political Economics; and Baldwin, "The Political Economy of Trade Policy."

${ }^{80}$ See R. Douglas Arnold, The Logic of Congressional Action (New Haven: Yale University Press, 1990); Dani Rodrik, "The Rush to Free Trade in the Developing World: Why So Late? Why Now? Will it Last?" National Bureau of Economic Research, Working Paper No. 3947, 1992; Author (1993).

${ }^{81}$ Mancur Olson, The Logic of Collective Action: Public Goods and the Theory of Groups (Cambridge: Harvard University Press, 1965); Ibid., The Rise and Decline of Nations: Economic Growth, Stagflation, and Social Rigidities (New Haven: Yale University Press, 1982); Lavergne, The Political Economy of U.S. Tariffs; Bruno S. Frey, International Political Economics ((Oxford: Basil Blackwell, 1984); David A. Lake, "The State and American Trade Strategy in the Pre-Hegemonic Era," International Organization 42 (1988), pp. 33-58.

${ }^{82}$ Milner, "Trading Places;" Ibid., Resisting Protectionism.

${ }^{83}$ In this sense, the model goes beyond the existing literature more generally. Explanations based on the American case, like those of Ferguson and Frieden for example, which hold that the increased competitiveness of US industry in the 1920s and 1930s led to the push for internationalism, are able to show only why government changed its trade policy (Ferguson, "From Normalcy to New Deal;" Frieden, "Sectoral Conflict and Foreign Economic Policy." See also Judith Goldstein, "Ideas, Institutions, and American Trade Policy," International Organization 42 (1988), pp. 179-217). They provide no explanation of why the protectionist industrial bloc, still politically powerful in the mid-1930s, was virtually a spent force by the end of the decade. 
protectionist businesses tend to be culled from the population, business is more likely to support free trade policies well into the future.

The model also is consistent with Olson's argument that traditionally stable systems encourage the proliferation of rent-seekers. ${ }^{34}$ The shocks provided by exogenous forces (such as crisis), or by governments seeking to reduce deadweight costs, prove fatal to inflexible rentseekers sheltered in the rarified atmosphere of the protected economy.

Finally, the model appears promising as at least a partial explanation for other cases where dominant economic interests rapidly shifted trade policy preferences. For example, although agricultural elites strongly resisted the repeal of the Corn Laws in Great Britain (1846), free trade was supported by both agricultural and industrial interests alike for decades thereafter. ${ }^{85}$ More recently, throughout Central and South America, countries that previously had been beholden to rent-seekers demanding policies of ISI and high barriers to imports, have begun to advocate liberalization of trade. Indeed, much of the enthusiasm for the possible extension of NAFTA to other parts of Latin America comes from countries that prior to the 1980s were not even members of the GATT. This suggests that trade liberalization may not be as politically intractable as many had believed. It suggests, in other words, that rent-seeking has its limits.

${ }^{84}$ Olson, The Rise and Decline of Nations.

${ }^{85}$ Author, 1994. 


\section{Figure 1}

Rent-Seekers and the Reduction of State-Supplied Rents

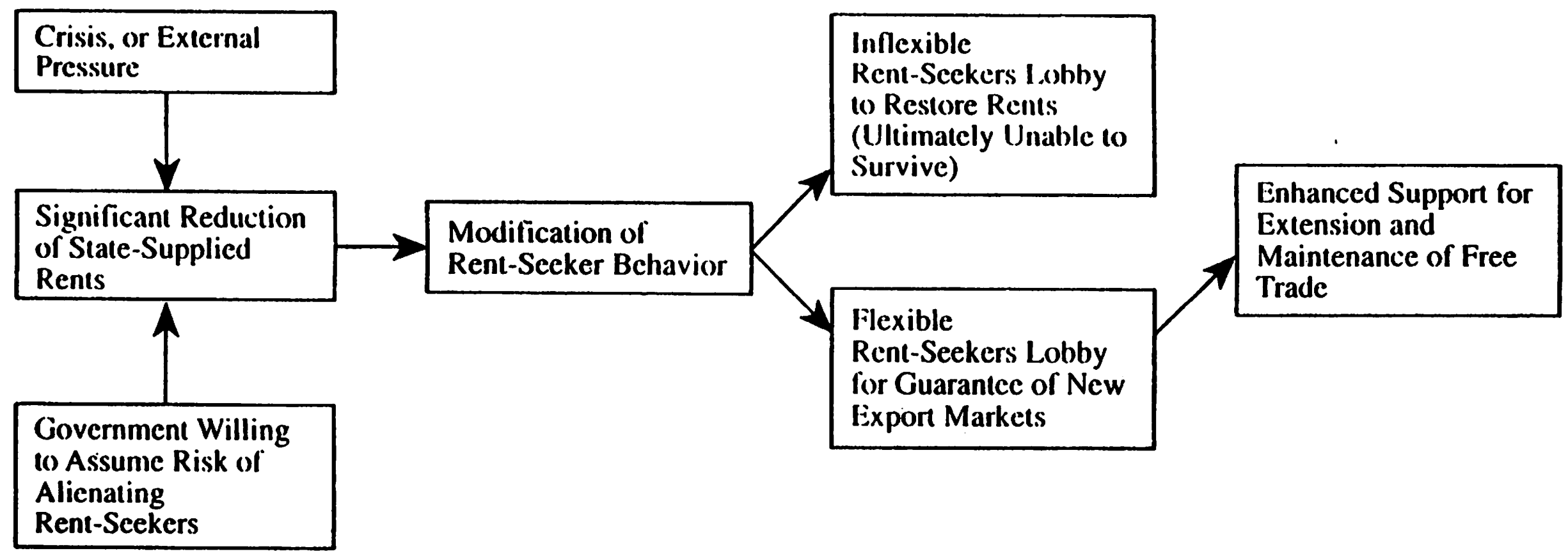

